Surface Phenomena and

Additives in Water-Based Coatings
and Printing Technology 


\section{Surface Phenomena and Additives in Water-Based Coatings and Printing Technology}

Edited by

Mahendra K. Sharma

Eastman Kodak Company

Kingsport, Tennessee

Springer Science+Business Media, LLC 


\section{Library of Congress Cataloging in Publication Data}

Surface phenomena and additives in water-based coatings and printing technology / edited by Mahendra K. Sharma.

p. $\quad \mathrm{cm}$.

"Proceedings of the International Symposium on Surface Phenomena and Additives in WaterBased Coatings and Printing Technology, sponsored by the Twenty-First Annual Meeting of the Fine Particle Society, held August 21-25, 1990, in San Diego, California"-T.p. verso.

Includes bibliographical references and index.

1. Paper coatings -Congresses. 2. Printing-ink-Congresses. 3. Surface chemistry-Congresses. I. Sharma, Mahendra K. II. International Symposium on Surface Phenomena and Additives in WaterBased Coatings and Printing Technology (1990: San Diego, Calif.) III. Fine Particle Society, Meeting (21st: 1990: San Diego, Calif.)

TS1118.F5S87 1992

91-44998

$676^{\prime} .234-\mathrm{dc} 20$

CIP

Proceedings of the International Symposium on Surface Phenomena and Additives in Water-Based Coatings and Printing Technology, sponsored by the Twenty-First Annual Meeting of the Fine Particle Society, held August 21-25, 1990, in San Diego, California ISBN 978-1-4899-2363-9 ISBN 978-1-4899-2361-5 (eBook) DOI 10.1007/978-1-4899-2361-5

(C) 1991 Springer Science+Business Media New York

Originally published by Plenum Press, New York in 1991

Softcover reprint of the hardcover 1st edition 1991

All rights reserved

No part of this book may be reproduced, stored in a retrieval system, or transmitted in any form or by any means, electronic, mechanical, photocopying, microfilming, recording, or otherwise, without written permission from the Publisher 
Water-based technology has undergone revolutionary changes during the past two decades. Interest in the properties and uses of water-based coatings, paints and inks has continued to grow since the establishment of the Clean Air Act of 1970. The present book is devoted to recent developments and trends in water-based coating and ink technology. This volume is divided in three broad catagories: (1) Additives and Water-based Coating/Ink Systems, (2) surface Modifications and Wettability, and (3) Ink/Coating Formulations and Their characterization. The role of various additives to improve the performance and properties of water-based coatings with special reference to surface phenomena such as wettability, adhesion, surface energies, dispersion stability, particle size and size distribution are presented in these sections.

This volume documents the proceedings of the International Symposium on Surface Phenomena and Additives in Water-Based Coatings and Printing Technology sponsored by the 21st Annual Meeting of the Fine Particle Society (FPS). This meeting was held in San Diego, California, August 21-25, 1990. The symposium upon which this volume is based was organized in four sessions emphasizing several basic and applied aspects of water-based coatings and printing technology. Major topics discussed include advances in water-based technology, water-based flexo and gravure inks, hydrophobically-modified cellulosic thickeners, organosilicones, uv curable silicone release coatings, surface characterization of $\mathrm{TiO}_{2}$ pigments, polymer substrates, flexographic plates and coating films, pigment wetting and dispersing agents, hydrotrope effect in emulsion polymers, film thickness control, particle size measurements, rheological properties, and statistically designed mixtures for ink formulations.

Several processes occurring at molecular, microscopic and macroscopic levels in characterizing flow, levelling, defoaming, wetting and dispersing additives are described to minimize or eliminate the coating and printing defects. I hope that this book will serve its intended objective of summarizing various surface phenomena and additives in relation to water-based technology. In addition, it will be a valuable reference source for both novices and experts in the field of surface chemistry, chemical and environmental engineering, coating and printing processes, and water-based coatings, paints and ink formulation technology. 
I would like to convey my sincere thanks and appreciation to Dr. Paul D. Berger, Organics Division, Witco Corporation, for his assistance and support in organizing the symposium. I wish to convey my thanks to the members of the Fine Particle society for their cooperation and support that allowed me to invite many researchers from different countries to participate in the meeting. I also would like to thank the authors for their contributions, and the reviewers for their diligent and timely manuscript reviews. The views and conclusions expressed herein are those of the authors. Special thanks to Ms. Patricia M. Vann, Plenum Publishing Corporation for her continued interest in this project.

I would like to express my thanks to the appropriate management of the Eastman Chemical Company (ECC) for allowing me to participate in the organization of the symposium and to edit this proceedings volume. My special thanks are due to Mr. J. C. Martin, Mr. J. E. Dickert and Dr. G. J. O'Neill for their cooperation and understanding during the tenure of editing.

Last, but certainly not least, I am grateful to my colleagues and friends for their encouragement and assistance throughout this project. Also I would like to acknowledge the support, assistance and cooperation of my wife, Rama, in more ways than one, and extend the appreciation to my children (Amol and Anuj) for rendering home atmosphere conductive to work and for allowing me to spend many evenings and weekends working on this volume.

Kingsport, Tennessee

July 26, 1991 
CONTENTS

\section{ADDITIVES AND WATER-BASED COATING/INK SYSTEMS}

Advances in Water-Based Coatings and Printing Technology.............1

M. K. Sharma

The Effect of Conventional and Hydrophobically-Modified

cellulosic Thickeners on the Rheology of Latex

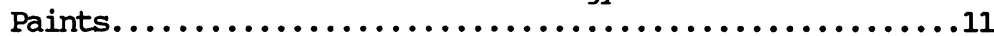

R. G. Brown, C. W. Vanderslice, T. S. Young and E. Fu

Water-Based Flexo and Gravure Inks Containing Eastman AQ

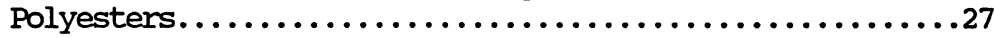

M. K. Sharma and H. D. Phan

Foaming and Crawling of Aqueous Industrial coatings..............43

M. J. Schnall

Silicones in the Coating Industry: Flow, Levelling

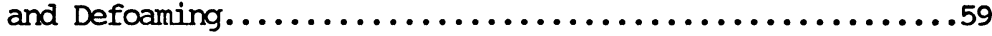

R. Vash

Organosilicone Surfactants: Properties, Chemistry, and

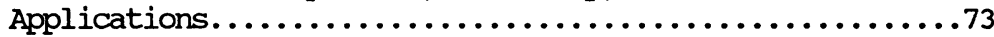

J. W. Adams

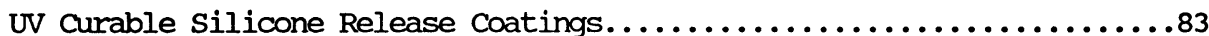

J. Stein, G. A. Smith and T. M. Leonard

SURFACE MODIFICATIONS AND WETTABIIITY

Surface Treatment of $\mathrm{TiO}_{2}$ Pigments and Aqueous Slurry

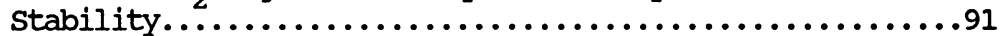

T. Losoi 
Titanium Dioxide Particle Size Control for Designed

Performance in Water-Borne Coating Systems..............105

C. C. Tatman

Pigment Wetting and Dispersing Additives for Water-Based

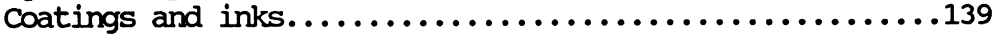

R. Vash

Surface Characterization of Polymer Substrates, Flexographic

Printing Plates and Dried Ink Films Printed with

Water-Based Ink Systems........................151

D. Kumar

A Dynamic Approach to Surface Energy and Wettability Phenomenon

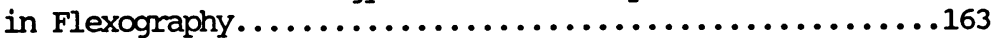

J. Domingue

Hydrotrope Effect in Emulsion Polymers: Surface Properties, Particle Size and Coagulum......................171

D. E. Nordhaus

Film Thickness control for Chemically Synthesized

Conducting Polypyrrole...........................179

M. M. Ayad, K. K. Kanazawa and J. C. Scott

INK/COATING FORMULATIONS AND THEIR CHARACTERIZATION

High Resolution Particle Size Analysis of Coating Materials:

II. Achieving Accurate and High Resolution

Results...................................191

J. C. Thomas

Comparison of New Methods of Laser Particle Analysis for the Range 0.0005 um to 700 um......................205

P. E. Plantz

Rheological Property Measurment with the Falling Needle

Viscometer: Theory............................225

N. A. Park and T. F. Irvine, Jr.

A Multifunctional Falling Needle Viscometer to measure Thermophysical Properties of Newtonian and

Non-Newtonian Fluids: Applications...............241

N. A. Park and T. F. Irvine, Jr.

Fundamentals of the Dispersion Process and Characterization of Coating Marterials Using Different Types of

Dispersion Equipment.........................255

G. Kigle-Boeckler

Surface Tension Measurement (Ring Method) and Characterization of Coating Materials...........................269

G. Kigle-Boeckler 
Ink Formulations Through Statistically Designed Mixture

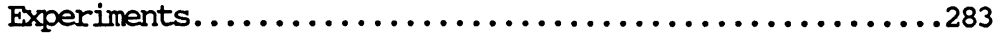

J. Auslander, W. Hunt and S. Wenner

Author Index.............................................. 307

Subject Index............................................ 